\title{
Colloidal Metal Oxide Nanoparticles Prepared by Laser Ablation Technique and Their Antibacterial Test
}

\author{
Johan S. Duque ${ }^{1, *\left(\mathbb{D}, \text { Brayan M. Madrigal }^{2}, \text { Henry Riascos }^{1} \text { and Yenny P. Avila }\right.}{ }^{2}$ \\ 1 Plasma, Laser and Applications Research Group, Basic Science Department, Technological University of \\ Pereira, A.A. 097, Pereira 660003, Colombia; jsd.optics@gmail.com \\ 2 Coordination and Organometallic Applied to Molecular Materials, Chemistry Department, Technological \\ University of Pereira, A.A. 097, Pereira 660003, Colombia; brayan.moreno@utp.edu.co (B.M.M.); \\ yennypatricia.avila@utp.edu.co (Y.P.A.) \\ * Correspondence: joseduque@utp.edu.co; Tel.: +57-301-355-6324
}

Received: 10 January 2019; Accepted: 31 January 2019; Published: 4 February 2019

\begin{abstract}
In this article we report the production of metal oxide $\left(\mathrm{TiFe}_{2} \mathrm{O}_{4}, \mathrm{ZnFe}_{2} \mathrm{O}_{4}\right)$ nanoparticles by pulsed laser ablation technique in a liquid environment. We used nanosecond Nd: YAG laser systems working at $532 \mathrm{~nm}$ and $1064 \mathrm{~nm}$ of wavelength and the energy of the laser beam was kept constant at $80 \mathrm{~mJ}$. Absorbance spectra, surface plasmon resonance, optical band-gap, and nanoparticle morphology were investigated using ultraviolet-visible (UV-Vis) spectroscopy, Fourier transform infrared spectroscopy (FTIR), and scanning electron microscopy (SEM). Changing the wavelength of the laser for growth, nanoparticles showed shift between the absorbance and surface plasmon resonance peaks in their UV-Vis spectra, which implies that the optical properties of the colloid nanoparticles depend on laser parameters. This was confirmed with the variation of the band gap energy. Furthermore, redshift for the absorbance peak was observed for samples as-grown at $532 \mathrm{~nm}$ around $150 \mathrm{~nm}$ as a function of time preparation. Conversely, for the samples as-grown at $1064 \mathrm{~nm}$ there was no shift in the absorbance spectra, which could be due to agglomeration and formation of larger particles. The characterization results showed appropriate plasmonic photo-catalysts properties of the particles, hence the photoactivation of the nanoparticles was examined on antibacterial effect using colonies of Staphylococcus aureus and Escherichia coli.
\end{abstract}

Keywords: metal nanoparticles; laser ablation; antibacterial effect; localized surface plasmon reference LSPR

\section{Introduction}

In recent years with the increasing applications of nanotechnology, nanomaterials like iron oxide $\left(\mathrm{Fe}_{3} \mathrm{O}_{4}\right)$, titanium oxide $\left(\mathrm{TiO}_{2}\right)$, and zinc oxide $(\mathrm{ZnO})$ have been observed to show great properties for applications in heavy metals removal from polluted water, industrial wastewater treatment, biomedicine and photocatalysts [1-7]. This feature is due to properties of nanoparticles as nano-adsorbents removing heavy ions and because of their size having the ability to interact with light, yielding the confinement of light inside the nanoparticles (NPs) which generates new non-linear phenomena such as the collective oscillations of conduction band electrons in spherical metal nanoparticles excited by external electromagnetic field, so-called localized surface plasmon resonance (LSPR). This phenomenon leads to a strong enhancement of the local electromagnetic fields surrounding the NPs at a specific wavelength. LSPR frequency can be tuned by changing the characteristics of the NPs, such as for example shape, size, and liquid environment. This is being 
widely used for medical applications of biological sensing systems, photovoltaic cells, and efficient catalysis processes like plasmonic solar desalination as reported by Tianyu Liu et al. 2016 [8,9].

Because the ideal plasmonic photocatalysts should simultaneously act as an absorber to capture light as well as a catalytic surface to interact properly with surface intermediates, metal nanoparticles with strong light absorption capability have been demonstrated as a new family of plasmonic photocatalysts that offer distinctly different benefits compared to conventional semiconductor photocatalysts. As an example of this, Jianlong Wang et al. 2010 have demonstrated that $\mathrm{Fe}_{3} \mathrm{O}_{4}$ magnetic nanoparticle can greatly enhance the localized surface plasmon resonance of metal nanoparticles in biological systems, and Nayareth Soltani et al. 2012 have reported the degradation of methylene blue by visible light induced in the presence of photocatalytic ZnS and CdS nanoparticles [10-14].

Iron oxide nanoparticles with titanium or zinc coupling can be a very promising photocatalytic system for both UV and visible light-induced reactions [15,16]. Zn and Ti NPs as surface modifiers of $\mathrm{Fe}_{2} \mathrm{O}_{4}$ can inhibit electron hole recombination under UV irradiation operating as an electron sink because the Fermi energy level of $\mathrm{Zn}$ and Ti lies below the conduction band of $\mathrm{Fe}_{2} \mathrm{O}_{4}$, and therefore photoexcited electrons in $\mathrm{Fe}_{2} \mathrm{O}_{4}$ can easily transfer the charge to $\mathrm{ZnO}$ and $\mathrm{TiO}_{2} \mathrm{NPs}[17,18]$. The advantage of functionalized bimetallic systems with a noble metal or semiconductors such as $\mathrm{TiFe}_{2} \mathrm{O}_{4}$ and $\mathrm{ZnFe}_{2} \mathrm{O}_{4}$ is that they can activate $\mathrm{Fe}_{2} \mathrm{O}_{4}$ towards visible light and UV light due to localized surface plasmon resonance of the metal, which together with the catalytic property of iron oxide, has become known recently as plasmonic photocatalysts [19-21]. The mechanism of plasmonic photocatalysts can be used especially in processes involving chemical transformations, for example in degradation process of polluting substances or industrial wastewater treatment where it is possible to use the iron as catalyst and enhance plasmonic properties by doping with a semiconductor and adding light [20-22].

Pulsed laser ablation method in a liquid environment has been studied as a new alternative to the preparation of nanoparticles without contamination [23-29]. Moreover, this technique is being widely studied for the practical design of nanoparticle structure, the distribution of size, and morphology by changing experimental parameters such as wavelength, pulse duration, laser fluence, pulse repetition rate, and exposure time. This is very useful when modifying the optical properties of metal nanoparticles [26,27]. In this work, metal oxide nanoparticles (MO NPs) were prepared by laser ablation technique in a liquid environment. Optical properties of the colloidal NPs were investigated using UV-Vis absorbance spectroscopy and Fourier transform infrared spectroscopy (FTIR) and nanoparticle morphology was analyzed with scanning electron microscopy (SEM). In addition, in the present work, synthesized nanoparticles are proposed for use as antibacterial surfaces in a microbiological system by photoactivation of NPs. Thus, their antibacterial effect on colonies of Staphylococcus aureus and Escherichia coli was studied.

\section{Materials and Methods}

\subsection{Synthesis of Metal Oxide Nanoparticles}

Figure 1 shows the schematic optical set-up used for pulsed laser ablation in a liquid environment and the samples prepared. Deionized water at room temperature was put in a glass beaker until $4 \mathrm{~mm}$ above the surface of the target. The laser beam was focused, with a semispherical lens on the surface of a solid rotating target through the solvent. We used a short-pulse, Q-Switched Nd: YAG laser (Spectra Physics, Santa Clara, CA, USA) which provided $7 \mathrm{~ns}, 80 \mathrm{~mJ}$ pulses at a wavelength of $1064 \mathrm{~nm}$ and in its harmonic $532 \mathrm{~nm}$ with a repetition rate of $10 \mathrm{~Hz}$ and $20 \mathrm{~Hz}$ for each wavelength respectively. The fluence was $0.8 \mathrm{~J} / \mathrm{cm}^{2}$ for $1064 \mathrm{~nm}$ and $532 \mathrm{~nm}$. The colloidal NP samples were prepared from $\mathrm{TiFe}_{2} \mathrm{O}_{4}$ and $\mathrm{ZnFe}_{2} \mathrm{O}_{4}$ solid targets and were ablated for $15 \mathrm{~min}$ in $6 \mathrm{~mL}$ of liquid. 


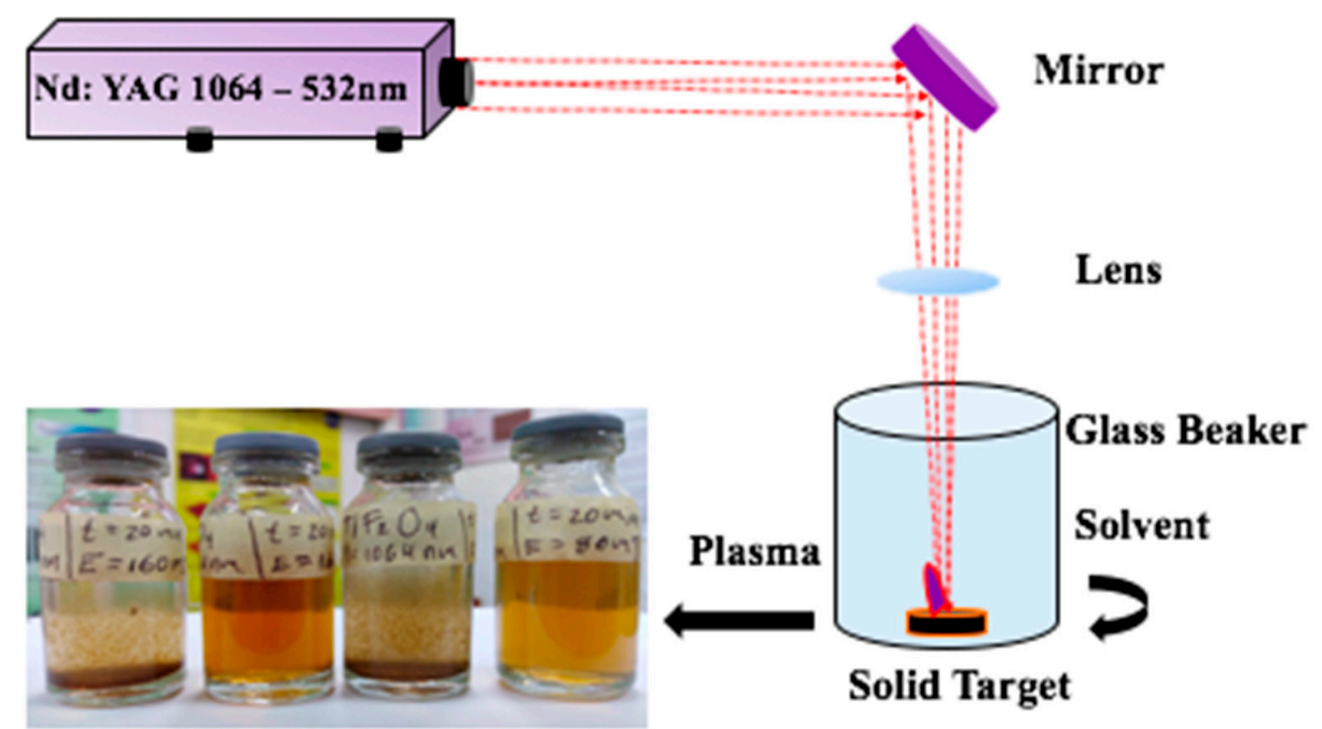

Figure 1. Experimental set-up used for laser ablation in a liquid environment for colloidal nanoparticle (NP) preparation.

\subsection{Characterizations of Metal Oxide Nanoparticles}

The optical properties of the NPMs synthesized were investigated with UV-Vis spectroscopy using a UV-visible spectrophotometer Evolution 201/220 from the Thermo Scientific series (Thermo Electron Scientific Instruments LLC, Madison, WI, USA) of quartz cuvettes with an optical path of $1 \mathrm{~cm}$. To determine vibration modes of NPs we used infrared spectroscopy by Fourier transform using an Agilent Carry 630 FTIR Infrared spectrometer (Agilent, Santa Clara, CA, USA). The SEM micrographs used to study structure and shape were obtained with a Phenom XL electronic scanning microscope (Thermo Fisher Scientific, Waltham, MA, USA) in standard mode with an acceleration voltage range between $10 \mathrm{kV}$ and $15 \mathrm{kV}$.

\subsection{Microbiological Experiment}

The batch experiments were done in triplicate. One to three isolated colonies of S. aureus and E. coli were taken in selective media such as Baird Parker agar and EMB (Eosin and Methylene Blue) agar, then transferred to $9 \mathrm{~mL}$ of infusion-brain-heart (IBH) broth and incubated at $37^{\circ} \mathrm{C}$, with shaking. Dilutions were made until reaching an optical density at $540 \mathrm{~nm}$ between 0.4 and 0.6 using the McFarland standard method corresponding to the exponential phase of growth. Subsequently, $100 \mu \mathrm{L}$ of the inoculum was taken and transferred to a Petri dish containing $20 \mathrm{~mL}$ of IBH agar and incubated at 37 ${ }^{\circ} \mathrm{C}$ after agitation to homogenize the growth of microorganisms in the environment.

\section{Results and Discussion}

\subsection{UV-Vis Analysis}

MONPs exhibit surface plasmon resonance peak in $300 \mathrm{~nm}$ and $271 \mathrm{~nm}$ for $\mathrm{TiFe}_{2} \mathrm{O}_{4}$ and $\mathrm{ZnFe}_{2} \mathrm{O}_{4}$, respectively, produced with a wavelength of $1604 \mathrm{~nm}$ (Figure 2a). For MONPs produced with a wavelength of $532 \mathrm{~nm}$ no peak formation is observed (Figure $2 \mathrm{~b}$ ). The absorption spectra of $\mathrm{TiFe}_{2} \mathrm{O}_{4}$ and $\mathrm{ZnFe}_{2} \mathrm{O}_{4}$ nanoparticles is shown in Figure 2. These spectra reveal that the maximum value appears in the UV region, which is the characteristic absorption edge of this type of ferrite NP. In addition, the sharp peak indicates the formation of stable colloidal suspension [28]. The difference between Figure $2 \mathrm{a}, \mathrm{b}$ indicates a change in concentration as in the nanostructure of the nanoparticles. On the other hand, the noise that presents the spectra at $1064 \mathrm{~nm}$ indicates a higher production of nanoparticles than for those prepared with a wavelength of $532 \mathrm{~nm}$. 

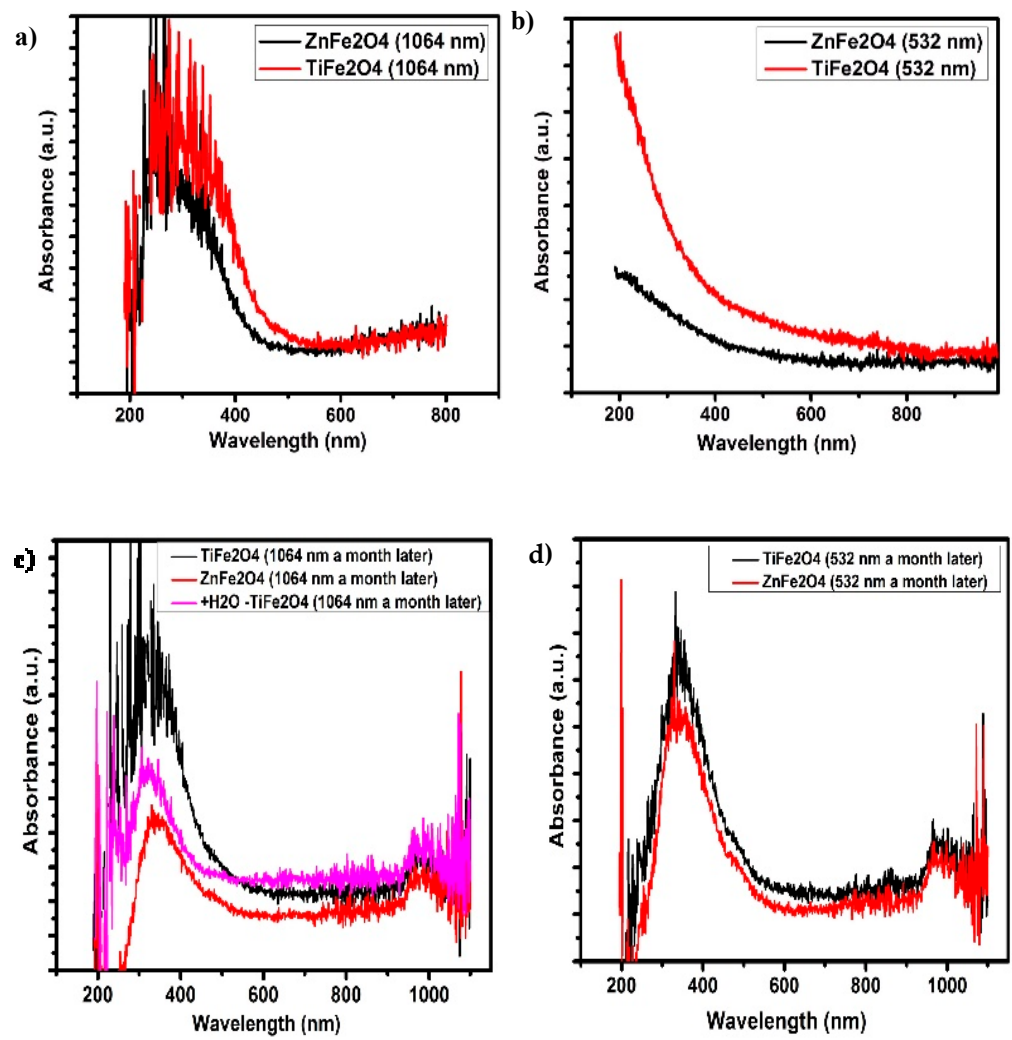

Figure 2. UV-Vis absorbance spectra of metal oxide nanoparticles (MONPs) produced with laser ablation technique in water at $(\mathbf{a}, \mathbf{c}) 1064$ and $(\mathbf{b}, \mathbf{d}) 532 \mathrm{~nm}$ wavelengths.

The bands around 210 and $270 \mathrm{~nm}$ in Figure 2a may be attributed to the charge transfer bands that have the $\mathrm{Fe}^{3+}$ of the iron ions isolated in tetrahedral (Td) and octahedral $(\mathrm{Oh})$ coordination, respectively [29]. The peak around $330 \mathrm{~nm}$ is assigned to $\mathrm{Fe}^{3+}$ isolated in any of the ulvospinel [30,31]. In addition, the absorption region between 200 and $300 \mathrm{~nm}$ in Figure $2 \mathrm{~b}$ could also be assigned to the charge transfer between the oxygen ions and the $\mathrm{Fe}^{3+}$ ions [32]. In this range, there is a superposition of the iron and oxygen charge transfer bands. The analysis carried out by UV-Vis-DRS suggests the presence of the ulvospinel of $\mathrm{MFe}_{2} \mathrm{O}_{4}$, where $\mathrm{M}$ is $\mathrm{Ti}^{2+}$ or $\mathrm{Zn}^{2+}$, respectively; these are present as nanoparticles in two structures in tetrahedral coordinations and $\mathrm{M}$ in octahedral coordinations.

The Figure 2c,d show the spectra of colloidal MNPs a month after synthesis for $1064 \mathrm{~nm}$ and 532 $\mathrm{nm}$. For NPs prepared with the wavelength of $532 \mathrm{~nm}$, a peak around $350 \mathrm{~nm}$ appears, evidencing agglomeration and the formation of larger particles. This is in accordance with theory corresponding with LSPR [33-35]. In MONPs produced with a wavelength of $1064 \mathrm{~nm}$, change is observed. For both samples, a new peak with lower intensity is observed around $970 \mathrm{~nm}$, which corresponds to new modes of oscillation of the agglomerated nanoparticles. These results show enhancement of the LSPR effect since the appearance of a new peak in the near-infrared region would improve the efficiency of this nanomaterial absorbing radiation. Table 1 shows the main parameter measured in the nanoparticle colloids of $\mathrm{TiFe}_{2} \mathrm{O}_{4}$ and $\mathrm{ZnFe}_{2} \mathrm{O}$ associate with the LSPR 4 .

From a quantum point of view, a high percentage of atoms is accumulated on the NPs' surfaces, exhibiting a special characteristic with light surface interaction like LSPR. These special characteristics are caused by the effects of the quantum confinement effect of metallic nanoclusters of $\mathrm{TiFe}_{2} \mathrm{O}_{4}$ and $\mathrm{ZnFe}_{2} \mathrm{O}_{4}$, which cannot be seen in bulk material [25,36,37]. The extra graph in Figure 2c corresponds to the NPs of $\mathrm{TiFe}_{2} \mathrm{O}_{4}$ that present greater noise, to which more water was added and a considerable reduction of noise was evidenced, which may be attributable to the formation of more NPs than in $\mathrm{ZnFe}_{2} \mathrm{O}_{4}$ colloids. Due to the saturation of solute in the samples, their stability decreased after they were prepared. 
Table 1. Principal absorbance peak of MONPs.

\begin{tabular}{ccccc}
\hline Metallic Target & \multicolumn{2}{c}{$\begin{array}{c}\text { 1064 nm } \\
\text { Peak Positions }\end{array}$} & \multicolumn{2}{c}{$\begin{array}{c}532 \mathbf{n m} \\
\text { Peak Positions }\end{array}$} \\
\hline & As-Growth & 1 Month & As- Growth & 1 Month \\
\hline $\mathrm{TiFe}_{2} \mathrm{O}_{4}$ & $300 \mathrm{~nm}$ & $325 \mathrm{~nm}$ & $210 \mathrm{~nm}$ & $342 \mathrm{~nm}$ \\
& & $970 \mathrm{~nm}$ & & $978 \mathrm{~nm}$ \\
\hline $\mathrm{ZnFe}_{2} \mathrm{O}_{4}$ & $271 \mathrm{~nm}$ & $343 \mathrm{~nm}$ & $200 \mathrm{~nm}$ & $346 \mathrm{~nm}$ \\
& & $975 \mathrm{~nm}$ & & $980 \mathrm{~nm}$ \\
\hline
\end{tabular}

\subsection{Band Gap Estimation}

The band gap is a key indicator of its light harvesting efficiency under solar illumination. To estimate the band gap energy of NPs we used Tauc's relation given by the equation using the data from UV-Vis absorption spectra for a direct band gap $n=\frac{1}{2}[38,39]$.

$$
(\alpha h v)^{\frac{1}{n}} \propto\left(h v-E_{g}\right)
$$

Band gap energy results for MONPs are shown in Table 2. The optical energy for $\mathrm{TiFe}_{2} \mathrm{O}_{4}$ and $\mathrm{ZnFe}_{2} \mathrm{O}_{4}$ changes slightly between $2.17 \mathrm{eV}$ and $2.27 \mathrm{eV}$ for $1064 \mathrm{~nm}$ and $532 \mathrm{~nm}$ and it does not present significant changes after one month of the synthesis which gives indications about the stability of the colloid over the time as can be seen in the method used, Figure 3a,b. These values are in accordance with those reported in previous works showing magnetic semiconductor behavior [40-43]. These results have a great variety of photocatalyst applications in environmental cleaning, since a small band gap is also important in any applications of NPs that involve light, as has been reported in previous works $[14,34]$.
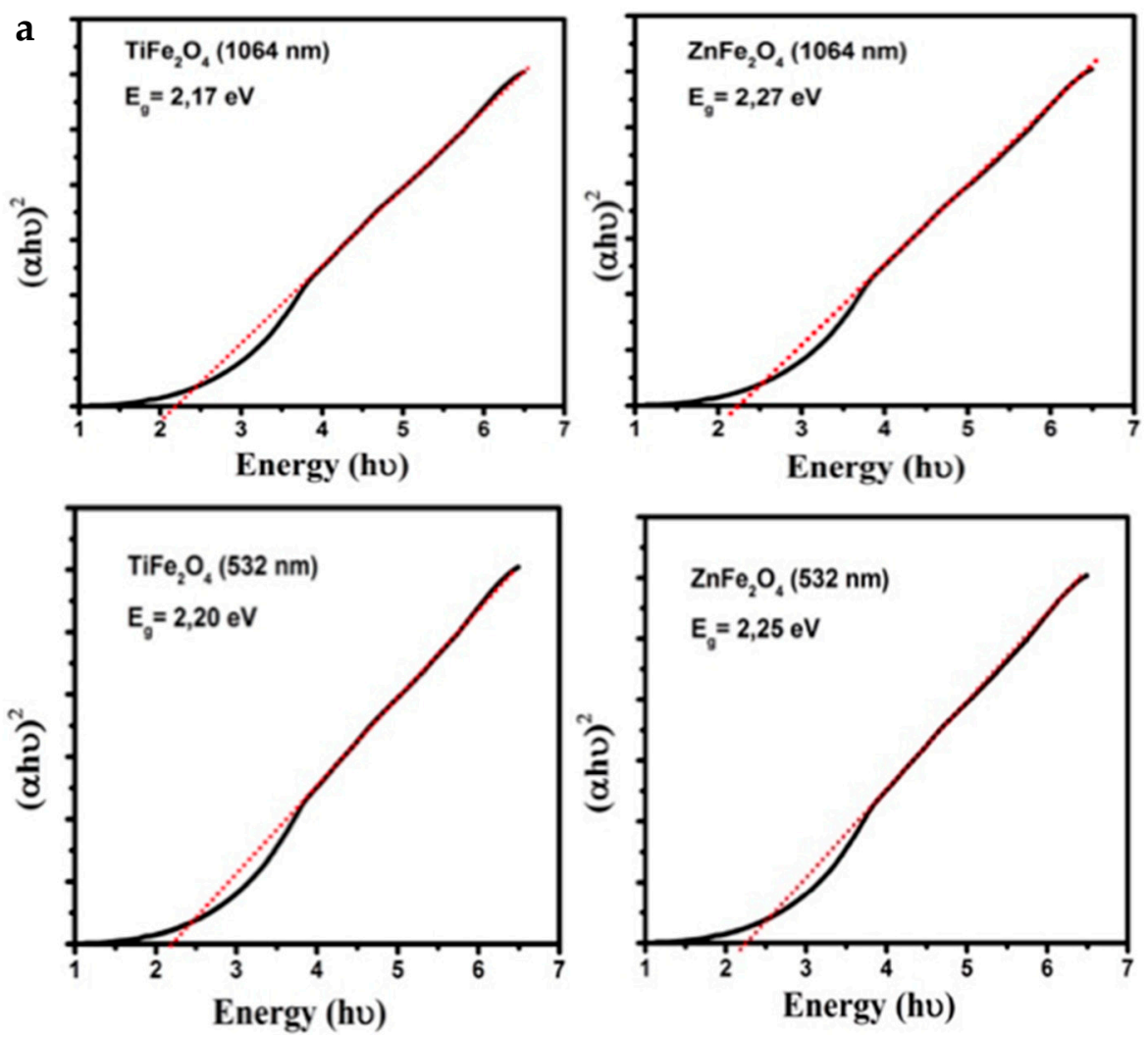

Figure 3. Cont. 

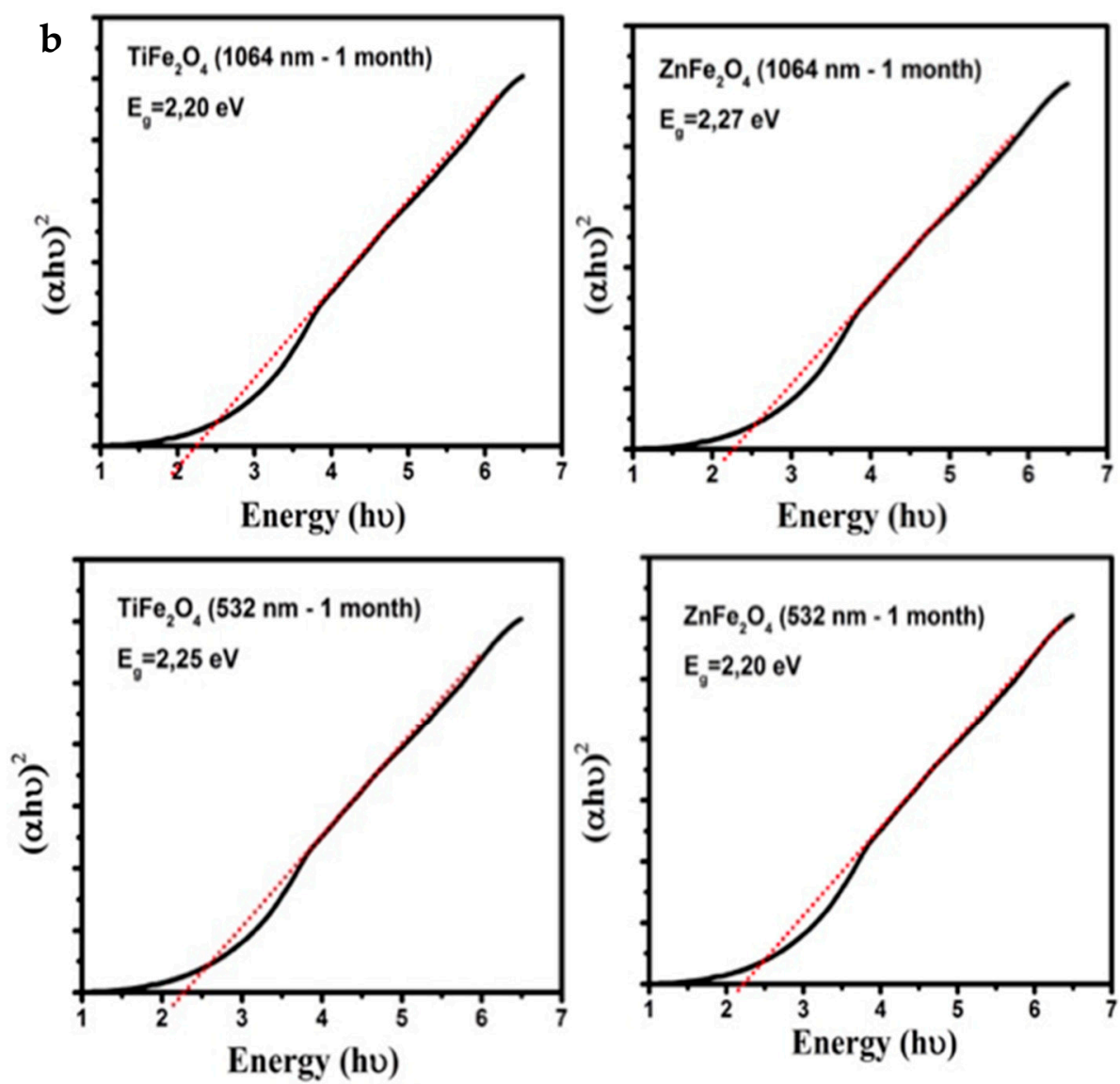

Figure 3. Optical band gap estimation of $\mathrm{TiFe}_{2} \mathrm{O}_{4}$ and $\mathrm{ZnFe}_{2} \mathrm{O}_{4}$ NPs produced with laser ablation technique in water at 1064 and $532 \mathrm{~nm}$ wavelengths (a) the day of growth (b) one month after the synthesis.

Table 2. Optical band gap of MONPs produced with laser ablation technique in water at 1064 and 532 nm wavelengths.

\begin{tabular}{ccccc}
\hline Target & $\mathrm{E}_{\text {gap (eV) }}$ at $\mathbf{1 0 6 4} \mathbf{~ n m}$ & $\mathrm{E}_{\text {gap (eV) }}$ at $\mathbf{1 0 6 4} \mathbf{~ n m ~ ( \mathbf { 1 ~ M o n t h ) ~ }}$ & $\mathrm{E}_{\text {gap }}(\mathbf{e V})$ at $\mathbf{5 3 2} \mathbf{~ n m}$ & $\mathbf{E}_{\text {gap (eV) }}$ at $\mathbf{5 3 2} \mathbf{~ n m ~ ( 1 ~ M o n t h ) ~}$ \\
\hline $\mathrm{TiFe}_{2} \mathrm{O}_{4}$ & 2.17 & 2.20 & 2.20 & 2.25 \\
$\mathrm{ZnFe}_{2} \mathrm{O}_{4}$ & 2.27 & 2.27 & 2.25 & 2.20 \\
\hline
\end{tabular}

\subsection{FTIR Analysis}

FTIR spectra of colloidal NPS are shown in Figure 4. An intense characteristic absorption band between $3300 \mathrm{~cm}^{-1}$ and $3500 \mathrm{~cm}^{-1}$ is observed, which can be assigned to the fundamental mode of vibration to $\mathrm{O}-\mathrm{H}$ stretching and deformation, due to water absorption, on the metal surface. Moreover, there appears to be a band between $1637 \mathrm{~cm}^{-1}$ and $2100 \mathrm{~cm}^{-1}$ which may be attributed to the scissor bending vibration of molecular water. Vibrational peaks around $415 \mathrm{~cm}^{-1}$ reveal mainly $\mathrm{Fe}-\mathrm{O}$ stretching vibration bonds. Appearance of peaks around $1600 \mathrm{~cm}^{-1}$ correspond to the overlapping of $\mathrm{Ti}-\mathrm{O}, \mathrm{Fe}-\mathrm{O}-\mathrm{Ti}, \mathrm{Zn}-\mathrm{O}$, and $\mathrm{Fe}-\mathrm{O}-\mathrm{Zn}$ bonds of ferrite nanoparticles. All samples synthetized exhibit similar FTIR spectra. These results indicate that the structure of the MONPs is not altered by infrared radiation, regardless of the wavelength of synthesis [33,37]. 


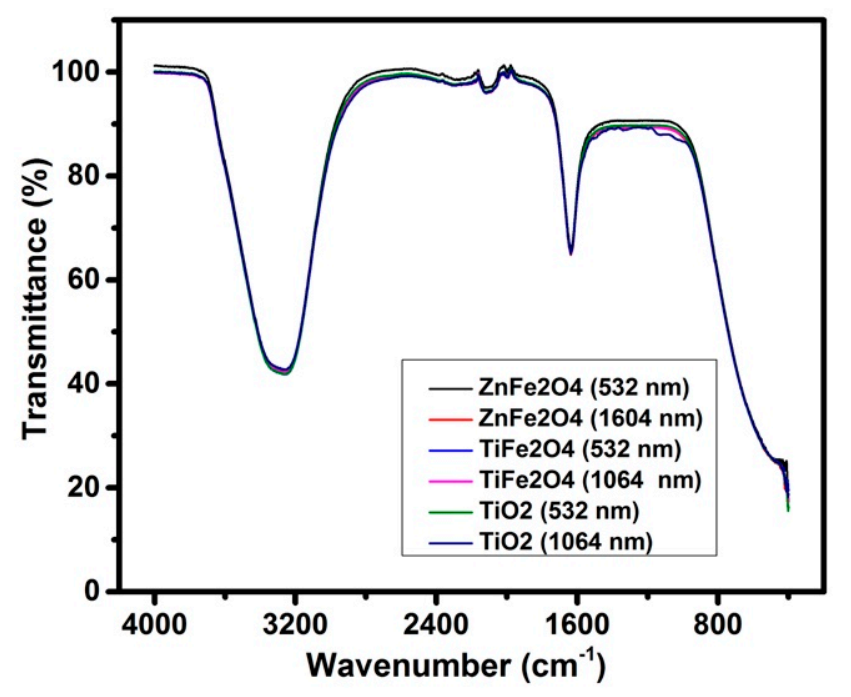

Figure 4. Fourier transform infrared spectroscopy (FTIR) transmittance spectra of MONPs produced with laser ablation technique in water at 1064 and $532 \mathrm{~nm}$ of wavelength.

\subsection{Scanning Electron Microscopy}

From SEM micrographs we observed that particles are spherical in shape and have a polidispersive particle size between $100 \mathrm{~nm}$ and $600 \mathrm{~nm}$. In Figure 5 is shown an SEM image of $\mathrm{TiFe}_{2} \mathrm{O}_{4}$ (left side) and $\mathrm{ZnFe}_{2} \mathrm{O}_{4}$ (right side). These nanoparticles were deposited over a substrate. In this image it is possible to observe morphological distribution of nanoparticles with different sizes over substrates. $\mathrm{ZnFe}_{2} \mathrm{O}_{4}$ has a tendency to form bigger clusters, which indicates that $\mathrm{ZnFe}_{2} \mathrm{O}_{4}$ was instable with precipitation in the colloid before the deposition on the substrate. Furthermore, in Figure 6 is presented the magnification of $\mathrm{TiFe}_{2} \mathrm{O}_{4}$ samples which shown that $\mathrm{Ti}$ is incorporated with $\mathrm{Fe}$ to form spherical-like structures typical of the metal nanoparticles prepared by laser ablation method [26,27]. In addition, after one month, all samples exhibit agglomeration due to highly magnetic behavior of titanium or zinc ferrite nanoparticles as has been reported in the literature $[28,33]$.
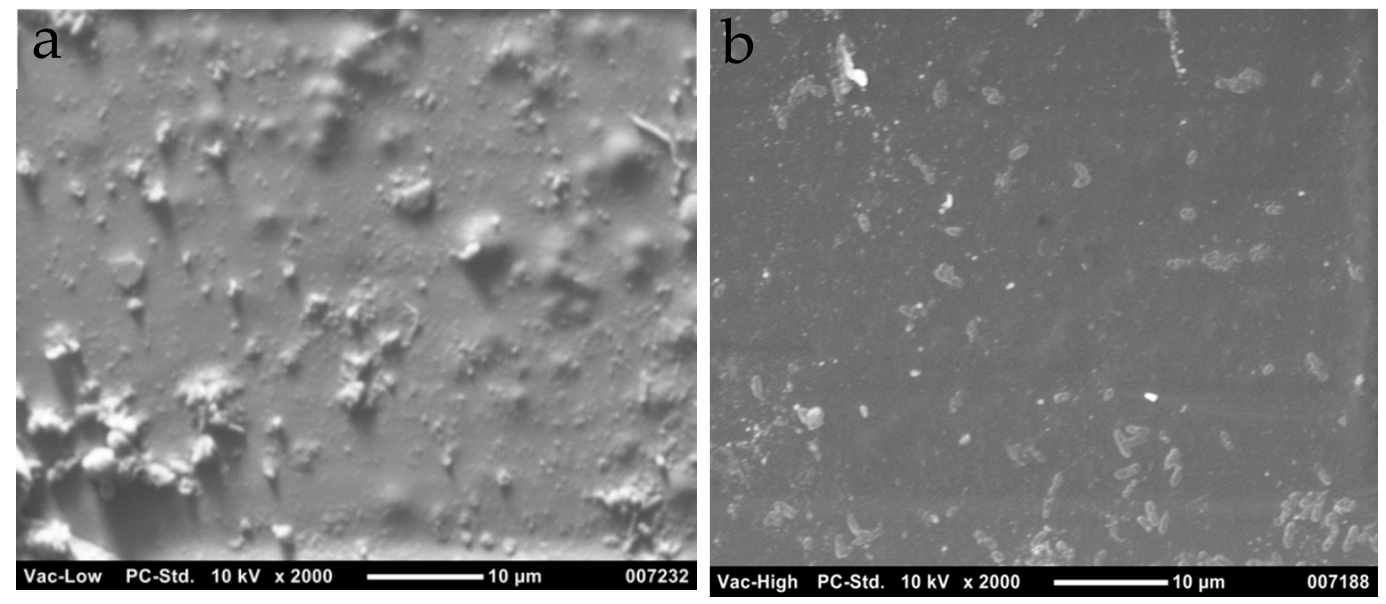

Figure 5. Scanning electron microscopy (SEM) images of (a) $\mathrm{TiFe}_{2} \mathrm{O}_{4}$ and (b) $\mathrm{ZnFe}_{2} \mathrm{O}_{4}$ nanoparticles dried over silica substrate. 

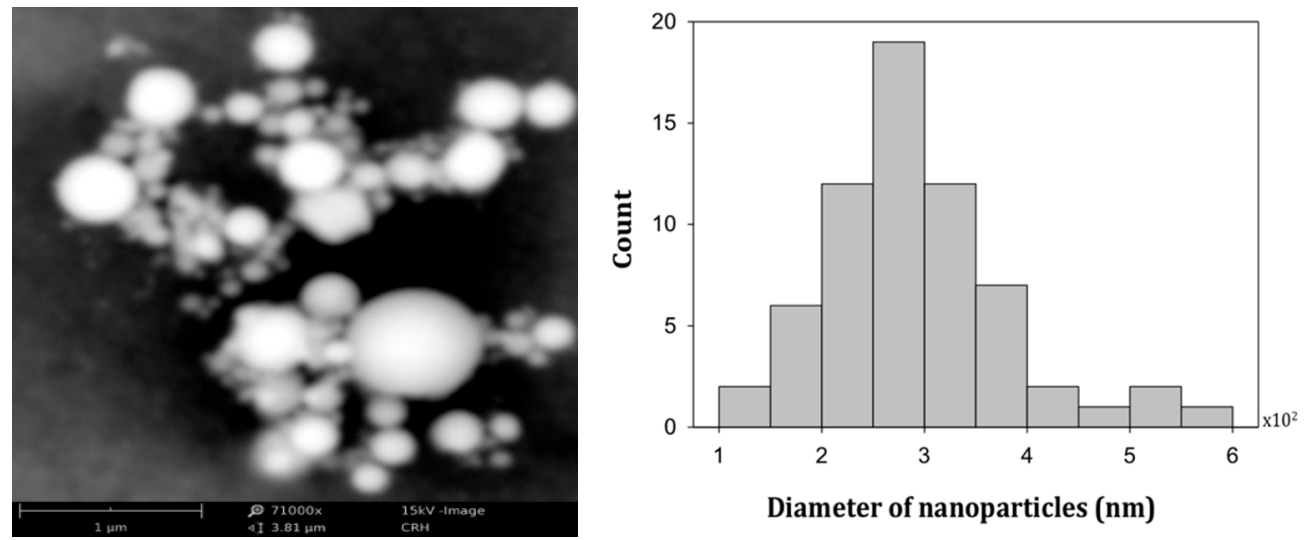

Figure 6. SEM images of magnification of $\mathrm{TiFe}_{2} \mathrm{O}$ NPs dried over Si substrate and size histogram.

\section{Application as Antibacterial Surfaces}

The sensitivity of strains of $S$. aureus and E. coli were determined using the method of planting by depth according to the Institute of Clinical and Laboratory Standards (CLSI, 2015). Seeding was performed in triplicate in each programmed experiment, with two incubation periods of 24 and $48 \mathrm{~h}$ at $37^{\circ} \mathrm{C}$, modifying their exposure to visible light and UV light for $2 \mathrm{~h}$ in some cases. The antibiotic used as a positive control was reactive grade ampicillin, which had a concentration of $1000 \mathrm{ppm}$ and DMSO as target at $5 \%$. Three squares of residual polyethylene with an area of $0.25 \mathrm{~cm}^{2}$ were placed in triplicate, with nanoparticles deposited which were labeled as follows: $\mathrm{A}\left(\mathrm{TiFe}_{2} \mathrm{O}_{4}, 1064 \mathrm{~nm}, 100 \mathrm{~mJ}\right)$, $\mathrm{B}\left(\mathrm{TiFe}_{2} \mathrm{O}_{4}, 1064 \mathrm{~nm}, 80 \mathrm{~mJ}\right), \mathrm{C}\left(\mathrm{ZnFe}_{2} \mathrm{O}_{4}, 1064 \mathrm{~nm}, 80 \mathrm{~mJ}\right), \mathrm{D}\left(\mathrm{TiFe}_{2} \mathrm{O}_{4}, 532 \mathrm{~nm}, 80 \mathrm{~mJ}\right), \mathrm{E}\left(\mathrm{ZnFe}_{2} \mathrm{O}_{4}\right.$, $1064 \mathrm{~nm}, 84 \mathrm{~mJ})$, and $\mathrm{F}\left(\mathrm{ZnFe}_{2} \mathrm{O}_{4}, 532 \mathrm{~nm}, 80 \mathrm{~mJ}\right)$. This can be seen in Figure 7. Subsequently, all samples were exposed to UV radiation at $330 \mathrm{~nm}$ for a time of $2 \mathrm{~h}$; in comparison to antibacterial activity in the absence of light, the NPs showed enhancement of antibacterial activity when they were illuminated with UV light, which indicates the photo activation of their plasma oscillation at surface of the NPs such that it interacts strongly with the bacteria, preventing its spread via thermal effect. For interpretation of the results, the strains were classified as susceptible, intermediate, or resistant with respect to the evaluated nanoparticles, measuring the inhibition halo (CLSI, 2015). The results are displayed in Table 3 [44-48]. In this experiment, nanoparticles of $\mathrm{TiFe}_{2} \mathrm{O}_{4}$ prepared at $532 \mathrm{~nm}$ showed better anti-bacterial results, exhibiting an inhibition ring $30 \mathrm{~mm}$ in diameter in samples deposited in polyethylene substrates when they was illuminated with UV light at $330 \mathrm{~nm}$.
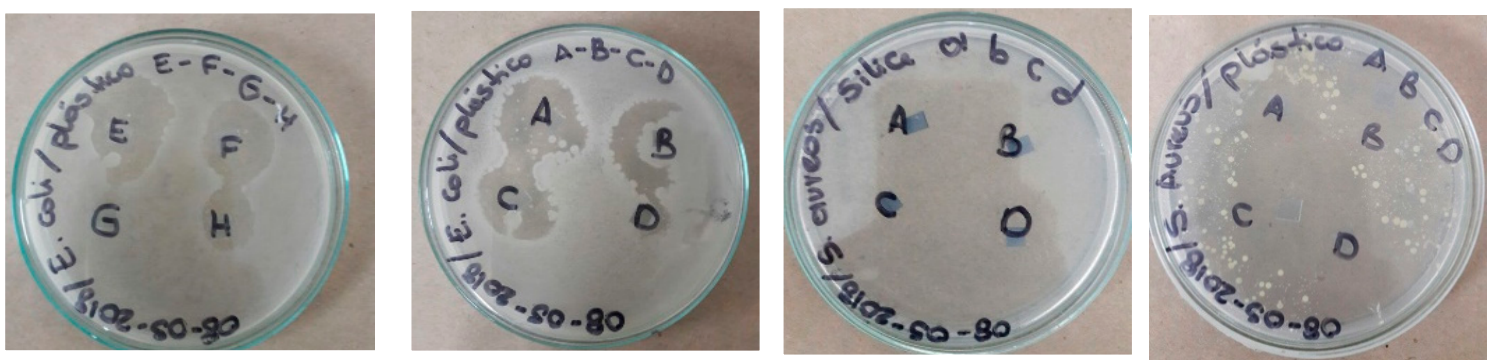

Figure 7. Antibacterial activity in colonies of Escherichia coli and Staphylococcus aureus. 
Table 3. Measurements of the inhibition ring according to the Institute of Clinical and Laboratory Standards (CLSI, 2015).

\begin{tabular}{|c|c|c|c|c|c|c|c|c|}
\hline \multirow{3}{*}{$\begin{array}{c}\text { NPs } \\
\text { Incubation time at } 37^{\circ} \mathrm{C}\end{array}$} & \multicolumn{4}{|c|}{ Illuminated at $330 \mathrm{~nm}(\mathrm{~h})$} & \multicolumn{4}{|c|}{ Without Light (h) } \\
\hline & \multicolumn{2}{|c|}{ S. aureus } & \multicolumn{2}{|c|}{ E. coli } & \multicolumn{2}{|c|}{ S. aureus } & \multicolumn{2}{|c|}{ E. coli } \\
\hline & 24 & 48 & 24 & 48 & 24 & 48 & 24 & 48 \\
\hline $\mathrm{TiFe}_{2} \mathrm{O}_{4}, 1064 \mathrm{~nm}$ & $23 \mathrm{~mm} \pm 0.1 \mathrm{~S}$ & $24 \mathrm{~mm} \pm 0.1 \mathrm{~S}$ & $23 \mathrm{~mm} \pm 0.1 \mathrm{~S}$ & $24 \mathrm{~mm} \pm 0.1 \mathrm{~S}$ & $\mathrm{R}$ & $\mathrm{R}$ & $\mathrm{R}$ & $\mathrm{R}$ \\
\hline $\mathrm{TiFe}_{2} \mathrm{O}_{4}, 532 \mathrm{~nm}$ & $30 \mathrm{~mm} \pm 0.3 \mathrm{~s}$ & $30 \mathrm{~mm} \pm 0.1 \mathrm{~S}$ & $28 \mathrm{~mm} \pm 0.3 \mathrm{~S}$ & $29 \mathrm{~mm} \pm 0.3 \mathrm{~S}$ & $\mathrm{R}$ & $\mathrm{R}$ & $\mathrm{R}$ & $\mathrm{R}$ \\
\hline $\mathrm{ZnFe}_{2} \mathrm{O}_{4}, 1064 \mathrm{~nm}$ & $17 \mathrm{~mm} \pm 0.1 \mathrm{I}$ & $18 \mathrm{~mm} \pm 0.2 \mathrm{I}$ & $9.7 \mathrm{~mm} \pm 0.2 \mathrm{R}$ & $10 \mathrm{~mm} \pm 0.3 \mathrm{R}$ & $\mathrm{R}$ & $\mathrm{R}$ & $\mathrm{R}$ & $\mathrm{R}$ \\
\hline $\mathrm{ZnFe}_{2} \mathrm{O}_{4}, 532 \mathrm{~nm}$ & $19 \mathrm{~mm} \pm 0.3 \mathrm{I}$ & $19 \mathrm{~mm} \pm 0.1 \mathrm{I}$ & $20 \mathrm{~mm} \pm 0.1 \mathrm{~S}$ & $21 \mathrm{~mm} \pm 0.2 \mathrm{~S}$ & $\mathrm{R}$ & $\mathrm{R}$ & $\mathrm{R}$ & $\mathrm{R}$ \\
\hline Polyethylene & $\mathrm{R}$ & $\mathrm{R}$ & $\mathrm{R}$ & $\mathrm{R}$ & $\mathrm{R}$ & $\mathrm{R}$ & $\mathrm{R}$ & $\mathrm{R}$ \\
\hline $\begin{array}{l}\text { Positive control } \\
\text { (ampicillin) }\end{array}$ & $23 \mathrm{~mm}$ & $23 \mathrm{~mm}$ & $23 \mathrm{~mm}$ & $23 \mathrm{~mm}$ & $23 \mathrm{~mm}$ & $23 \mathrm{~mm}$ & $23 \mathrm{~mm}$ & $23 \mathrm{~mm}$ \\
\hline
\end{tabular}

S (Sensitive, $\geq 20 \mathrm{~mm}$ ), I (Intermediate, 15-20 mm), R (Resistant, $\leq 14),($ CLSI, 2015).

\section{Conclusions}

In summary, in this study metal oxide nanoparticles were prepared by laser ablation technique. These MONPs had spherical forms with different sizes and showed the same color aspect. The $\mathrm{TiFe}_{2} \mathrm{O}_{4}$ NPs were more stable than $\mathrm{ZnFe}_{2} \mathrm{O}_{4}$ due to the last present fast agglomeration. Plasmon resonance peaks appeared at around $300 \mathrm{~nm}$ and $274 \mathrm{~nm}$ for $\mathrm{TiFe}_{2} \mathrm{O}_{4}$ and $\mathrm{ZnFe}_{2} \mathrm{O}_{4}$, respectively, and were produced at $1604 \mathrm{~nm}$. For nanoparticles produced at $532 \mathrm{~nm}$ we did not observe the formation of a peak. The maximum absorbance of radiation in the UV range was between $200 \mathrm{~nm}$ and $350 \mathrm{~nm}$, indicating the favorability of these NPs for applications in catalysts, photocatalysts, and surface processes. However, for both samples we found that the maximum absorbance of radiation was in the UV range but a month later we found that the NPs presented a new absorption band in the infrared range with low intensity, which is a good indicator of nanostructure modification. The optical properties of colloidal nanoparticles depends on the laser wavelength, which is manifested in the variation of the UV-Vis spectra and band gap energy. In batch experiments the $\mathrm{TiFe}_{2} \mathrm{O}_{4}$ nanoparticles prepared at $532 \mathrm{~nm}$ showed better anti-bacterial results, exhibiting an inhibition ring $30 \mathrm{~mm}$ in diameter in samples deposited in polyethylene substrates when illuminated with UV light at $330 \mathrm{~nm}$.

Author Contributions: Conceptualization, J.S.D. and B.M.M.; methodology, H.R. and J.S.D.; validation, Y.P.A. and H.R. formal analysis, J.S.D.; investigation, J.S.D. and B.M.M.; writing-Original draft preparation, J.S.D.; writing-Review and editing, J.S.D. and H.R.; supervision, Y.P.A. and H.R.; project administration, H.R. and Y.P.A.

Funding: The research was funded by Fondo Nacional de Financiación para la Ciencia la Tecnológia y la Investigación Francisco Jose de Caldas, N ${ }^{\circ} \mathrm{FP} 44842-393-2017$.

Acknowledgments: We acknowledge the financial support provided by Colciencias \& Vicerrectoria de Investigaciones Innovacion y Extension Universidad Tecnológica de Pereira (Convocatoria 775 Jovenes Investigadores por la paz 2017 codígo de proyecto JI3-18-1 y Proyecto 3-18-7). The authors are grateful for the peer review for the valuable suggestions.

Conflicts of Interest: The authors declare no conflict of interest.

\section{References}

1. Afshar, E.; Mohammadi-Manesh, H.; Khavidaki, H.D. Removal of $\mathrm{Hg}$ (I) and $\mathrm{Hg}$ (II) Ions from Aqueous Solutions, Using $\mathrm{TiO}_{2}$ Nanoparticles. Pollution 2017, 3, 505-516. [CrossRef]

2. Nica, I.C.; Stan, M.S.; Popa, M.; Chifiriuc, M.C.; Lazar, V.; Pircalabioru, G.G.; Dumitrescu, I.; Ignat, M.; Feder, M.; Tanase, L.C.; et al. Interaction of New-Developed $\mathrm{TiO}_{2}$-Based Photocatalytic Nanoparticles with Pathogenic Microorganisms and Human Dermal and Pulmonary Fibroblasts. Int. J. Mol. Sci. 2017, $18,249$. [CrossRef] [PubMed]

3. Tan, Y.N.; Ayob, M.K.; Yaacob, W.W.A. Purification and characterisation of antibacterial peptide-containing compound derived from palm kernel cake. Food Chem. 2013, 136, 279-284. [CrossRef] [PubMed]

4. Dave, P.N.; Chopda, L.V. Application of Iron Oxide Nanomaterials for the Removal of Heavy Metals. J. Nanotechnol. 2014, 2014, 396589. [CrossRef] 
5. Sharma, Y.C.; Srivastava, V.; Singh, V.K.; Kaul, S.N.; Weng, C.H. Nano-adsorbents for the removal of metallic pollutants from water and wastewater. Environ. Technol. 2009, 30, 583-609. [CrossRef] [PubMed]

6. Man, Z.; Ziyada, A.K.; Bustam, M.A.; Mutalib, A.; Wilfred, C.D. Thermophysical Properties of Dual Functionalized Imidazolium-Based Ionic Liquids. J. Environ. Chem. Eng. 2014, 2, 642-651. [CrossRef]

7. Sung, L.P.; Scierka, S.; Baghai-Anaraki, I.; Ho, D.L. Characterization of Metal-Oxide Nanoparticles: Synthesis and Dispersion in Polymeric Coatings. Mater. Res. Soc. 2003, 740. [CrossRef]

8. Yan, J.; Liu, P.; Ma, C.; Lin, Z.; Yang, G. Plasmonic near-touching titanium oxide nanoparticles to realize solar energy harvesting and effective local heating. Nanoscale 2016, 8, 8826-8838. [CrossRef]

9. Jensen, T.R.; Malinsky, M.D.; Christy, L. Tunable Localized Surface Plasmon Resonance Spectra of Silver Nanoparticles. Haynes. J. Phys. Chem. B 2000, 104, 10549-10556. [CrossRef]

10. Willets, K.A.; Van Duyne, R.P. Localized surface plasmon resonance spectroscopy and sensing. Annu. Rev. Phys. Chem. 2007, 58, 267-297. [CrossRef]

11. Soelberg, S.D.; Stevens, R.C.; Limaye, A.P.; Furlong, C.E. Surface Plasmon Resonance Detection Using Antibody-Linked Magnetic Nanoparticles for Analyte Capture, Purification, Concentration, and Signal Amplification. Anal. Chem. 2010, 82, 6782-6789. [CrossRef]

12. Murph, S.E.; Larsen, G.K.; Lascola, R.J. Multifunctional Hybrid Fe2O3-Au Nanoparticles for Efficient Plasmonic Heating. J. Vis. Exp. 2016, 108. [CrossRef]

13. Jung, M.; Ji, M.G.; Kim, T.R.; Shim, C.H.; Lee, S.; Woo, D.; Choi, Y.W. Localized surface plasmon resonance in two-dimensional silver nanodot array fabricated using nanoporous alumina mask for chemical sensor platform. Opt. Eng. 2016, 55. [CrossRef]

14. Soltani, N.; Saion, E.; Hussein, M.Z.; Erfani, M.; Abedini, A.; Bahmanrokh, G.; Navasery, M.; Vaziri, P. Visible light-induced degradation of methylene blue in the presence of photocatalytic ZnS and CdS nanoparticles. Int. J. Mol. Sci. 2012, 13, 12242-12258. [CrossRef] [PubMed]

15. Janczarek, M.; Kowalska, E. On the Origin of Enhanced Photocatalytic Activity of Copper-Modified Titania in the Oxidative Reaction Systems. Catalysts 2017, 7, 317. [CrossRef]

16. Yang, Y.T.; Zhu, J.F.; Liao, G.; Xu, H.J.; Yu, B. The Development of Biologically Important Spirooxindoles as New Antimicrobial Agents. Curr. Med. Chem. 2018, 25, 2233-2244. [CrossRef]

17. Jha, M.; Shimpi, N.G. Green synthesis of zero valent colloidal nanosilver targeting A549 lung cancer cell: In vitro cytotoxicity. J. Genet. Eng. Biotechnol. 2018, 16, 115-124. [CrossRef]

18. Kelly, K.L.; Coronado, E.; Zhao, L.L.; Schatz, G.C. The optical properties of metal nanoparticles: The influence of size, shape, and dielectric environment. J. Phys. Chem. B 2003, 107, 668-677. [CrossRef]

19. Hergert, W. Mie Theory, Springer Series in Optical Sciences. Mie Theory 2012, 169, 53. [CrossRef]

20. Zhang, X.; Chen, Y.L.; Liu, R.S.; Tsai, D.P. Plasmonic photocatalysis. Rep. Prog. Phys. 2013, 76. [CrossRef]

21. Yamashita, H.; LiY, H. Nanostructured Photocatalysts: Advanced Functional Materials. Appl. Catal. B 2011, 105, 211.

22. Li, S.; Wang, W.; Liang, F.; Zhang, W.X. Heavy metal removal using nanoscale zero-valent iron (nZVI): Theory and application. J. Hazard. Mater. 2017, 322, 163-171. [CrossRef] [PubMed]

23. Mansoureh, G.; Parisa, V. Synthesis of metal nanoparticles using laser ablation technique. Emerg. Appl. Nanopart. Archit. Nanostruct. 2018, 575-596. [CrossRef]

24. Ganjali, M.; Vahdatkhah, P.; Marashid, S.M.B. Synthesis of Ni Nanoparticles by Pulsed Laser Ablation Method in Liquid Phase. Procedia Mater. Sci. 2015, 11, 359-363. [CrossRef]

25. Hamad, A.; Li, L.; Liu, Z. Comparison of characteristics of selected metallic and metal oxide nanoparticles produced by picosecond laser ablation at 532 and $1064 \mathrm{~nm}$ wavelengths. Appl. Phys. A 2016, 122, 904. [CrossRef]

26. Bozon-Verduras, F.; Breyner, R.; Voronov, V.V. Production of nanoparticles by laser-induced ablation of metals in liquids. Quantum Electron. 2003, 33, 714-720. [CrossRef]

27. Khan, S.Z.; Yuan, Y.; Abdolvand, A.; Schmidt, M.; Couse, P.; Li, L. Generation and characterization of NiO nanoparticlesby continuous wave fiber laser ablation in liquid. J. Nanopart. Res. 2009, 11, 1421. [CrossRef]

28. Shukla, A.; Singh, S.C.; Pandey, B.K.; Uttam, K.N.; Shah, J.; Kotnala, R.K.; Gopal, R. Liquid-assisted pulsed laser ablation synthesized titanium ferrite nanoparticles: Structural, optical and magnetic properties. Adv. Mater. Lett. 2015, 6, 1066-1072. [CrossRef] 
29. Kawabata, T.; Fujisaki, N.; Shishido, T.; Nomura, K.; Sano, T.; Takehira, K. Improved Fe/Mg-Al hydrotalcite catalyst for Baeyer-Villiger oxidation of ketones with molecular oxygen and benzaldehyde. J. Mol. Catal. A Chem. 2006, 253, 279-289. [CrossRef]

30. Ohishi, Y.; Kawabata, T.; Shishido, T.; Takaki, K.; Zhang, Q.; Wang, Y.; Nomura, K.; Takehira, K. Mg-Fe-Al mixed oxides with mesoporous properties prepare from hydrotalcite as precursors: Catalytic behavior in ethylbenzene dehydrogenation. Appl. Catal. A Gen. 2005, 288, 220-223. [CrossRef]

31. Agúa, U.A.; Oliva, M.I.; Marchetti, S.G.; Heredia, A.C.; Casuscelli, S.G.; Crivello, M.E. Synthesis and characterization of a mixture of $\mathrm{CoFe}_{2} \mathrm{O}_{4}$ and $\mathrm{MgFe}_{2} \mathrm{O}_{4}$ from layered double hydroxides: Band gap energy and magnetic responses. J. Magn. Magn. Mater. 2013, 234, 38-46. [CrossRef]

32. Elıas, V.R.; Vaschetto, E.G.; Sapag, K.; Crivello, M.E.; Casuscelli, S.G.; Eime, G.A. Synthesis and Photocatalytic Activity of Titania-Loaded Transition Metal-Modified MCM-41 Molecular Sieves. Top. Catal. 2011, 54, 277-286. [CrossRef]

33. Ryu, J.H.; Yoon, J.W.; Lim, C.S.; Oh, W.C.; Shim, K.B. Microwave-assisted synthesis of $\mathrm{CaMoO}_{4}$ nano-powders by a citrate complex method and its photoluminescence property. J. Lumin. 2007, 124, 67-70. [CrossRef]

34. Shukla, A.; Bhardwaj, A.K.; Pandey, B.K.; Singh, S.C.; Uttam, K.N.; Shah, J.; Kotnala, R.K.; Gopal, R. Laser synthesized magnetically recyclable titanium ferrite nanoparticles for photodegradation of dyes. J. Mater. Sci. Mater. Electron. 2017, 28, 15380-15386. [CrossRef]

35. Duque, J.S.; Blandón, J.S.; Riascos, H. Localized Plasmon resonance in metal nanoparticles using Mie theory. J. Phys. Conf. Ser. 2017, 850. [CrossRef]

36. Gupta, S.M.; Manoj, T. A review of $\mathrm{TiO}_{2}$ nanoparticles. Chin. Sci. Bull. 2011, 56, 1639-1657. [CrossRef]

37. Akimoto, S. Takashi Katsura and Minoru Yoshida. J. Geomagn. Geoelectr. 1957, 9, 165-178. [CrossRef]

38. Tauc, J.; Grigorovici, R.; Vancu, A. Optical Properties and Electronic Structure of Amorphous Germanium. Phys. Status Solidi 1966, 15, 627. [CrossRef]

39. Ghobadi, N. Band gap determination using absorption spectrum fitting procedure. Int. Nano Lett. $2013,3$. [CrossRef]

40. Kirchberg, K.; Becker, A.; Bloesser, A.; Weller, T.; Timm, J.; Suchomski, C.; Marschall, R. Stabilization of Monodisperse, Phase-Pure MgFe2O4 Nanoparticles in Aqueous and Nonaqueous Media and Their Photocatalytic Behavior. J. Phys. Chem. C 2017, 121, 27126-27138. [CrossRef]

41. Sun, S.; Yang, X.; Zhang, Y.; Zhang, F.; Ding, J.; Bao, J.; Gao, C. Enhanced photocatalytic activity of sponge-like $\mathrm{ZnFe}_{2} \mathrm{O}_{4}$ synthesized by solution combustion method. Prog. Nat. Sci. 2012, 22, 639-643. [CrossRef]

42. Theivasanthi, T.; Alagar, M. Lead Nanopowder as Advanced Semi-Conductor, An Insight. Res. Appl. Mater. 2013, 1, 36-43. [CrossRef]

43. Baset, S.; Akbar, H. Size measurement of metal and semiconductor nanoparticles via uv-vis absorption spectra. Dig. J. Nanomater. Biostruct. 2011, 6, 709-716.

44. Horiuchi, Y.; Toyao, T.; Miyahara, K.; Zakar, L.; Van, D.D.; Kamata, Y.; Kim, T.H.; Lee, S.W.; Matsuok, M. Visible-light-driven photocatalytic water oxidation catalysed by iron-based metal organic frameworks. Carbohydr. Polym. 2016, 153, 60-65. [CrossRef] [PubMed]

45. Ghandoor, H.E.; Zidan, H.M.; Khalil, M.M.H.; Ismai, M.I.M. Synthesis and Some Physical Properties of Magnetite $\left(\mathrm{Fe}_{3} \mathrm{O}_{4}\right)$ Nanoparticles. Int. J. Electrochem. Sci. 2012, 7.

46. Taffa, D.H.; Dillert, R.; Ulpe, A.C.; Bauerfeind, K.C.L.; Bredow, T.; Bahnemann, D.W.; Wark, M. Photoelectrochemical and theoretical investigations of spinel type ferrites $\left(\mathrm{MxFe}_{3}-\mathrm{xO}_{4}\right)$ for water splitting: A mini-review. J. Photonics Energy 2016, 7. [CrossRef]

47. Dulub, O.; Diebold, U.; Kresse, G. Novel Stabilization Mechanism on Polar Surfaces: ZnO (0001)-Zn. Phys. Rev. Lett. 2003, 90, 016102. [CrossRef]

48. Ferreira, V.C.; Goddard, A.J.; Monteiro, O.C. In situ synthesis and modification of cotton fibers with bismuthoxychloride and titanium dioxide nanoparticles for photocatalytic applications. J. Photochem. Photobiol. A Chem. 2018, 357, 201-212. [CrossRef]

(C) 2019 by the authors. Licensee MDPI, Basel, Switzerland. This article is an open access article distributed under the terms and conditions of the Creative Commons Attribution (CC BY) license (http://creativecommons.org/licenses/by/4.0/). 